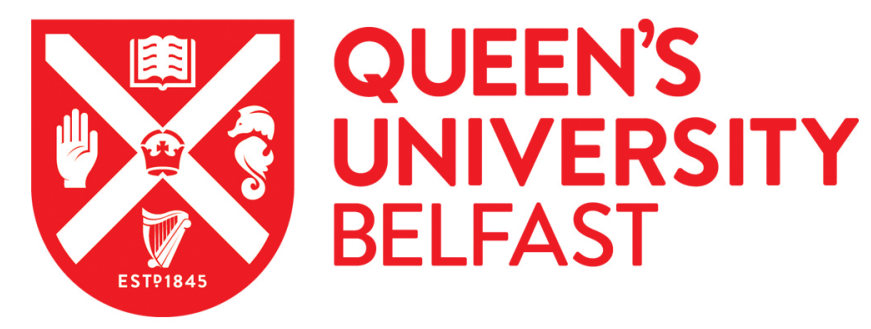

\title{
Scene From a Different Angle: Attempts to Internationalize Northern Ireland's Conflict Experience
}

Hayward, K. (2015). Scene From a Different Angle: Attempts to Internationalize Northern Ireland's Conflict Experience. Peace and Conflict: Journal of Peace Psychology , 21(4), 669-672.

https://doi.org/10.1037/pac0000118

Published in:

Peace and Conflict: Journal of Peace Psychology

Document Version:

Peer reviewed version

Queen's University Belfast - Research Portal:

Link to publication record in Queen's University Belfast Research Portal

Publisher rights

Copyright 2016 APA, all rights reserved

This article may not exactly replicate the authoritative document published in the APA journal. It is not the copy of record.

The final version is available at http://psycnet.apa.org/?\&fa=main.doiLanding\&doi=10.1037/pac0000118

\section{General rights}

Copyright for the publications made accessible via the Queen's University Belfast Research Portal is retained by the author(s) and / or other copyright owners and it is a condition of accessing these publications that users recognise and abide by the legal requirements associated with these rights.

Take down policy

The Research Portal is Queen's institutional repository that provides access to Queen's research output. Every effort has been made to ensure that content in the Research Portal does not infringe any person's rights, or applicable UK laws. If you discover content in the Research Portal that you believe breaches copyright or violates any law, please contact openaccess@qub.ac.uk. 
Author's pre-print June 2015.

'This article may not exactly replicate the final version published in the APA journal. It is not the copy of record.'

Published in: Peace and Conflict: Journal of Peace Psychology, Vol 21(4), Nov 2015, 669-672.

\section{Scene from a different angle: Attempts to internationalise Northern Ireland's conflict experience}

\section{Katy Hayward}

\section{Review Essay}

Timothy J. White (ed.) Lessons from the Northern Ireland Peace Process. University of Wisconsin Press, 2013. ISBN 978-0-2992-9704-7

Jennifer Curtis. Human Rights as War by Other Means. University of Pennsylvania Press, 2014. ISBN 978-08122-4619-3

Any peace process worth its salt should, it seems, be judged to offer 'lessons' to those with peacebuilding ambitions in other parts of the world. After allowing a respectable few years for the dust to settle, persons of note in any one of the convoys of negotiation behind an agreement feel justified - and are sometimes encouraged - to share their 'insights' from the particular tricky case that they had a hand in resolving... Except that, more often than not, the conflict is not resolved. Indeed, if the conflict is close enough for prospective readers of such memoirs to recall then it is almost inevitably still too far from resolution to be able to consider it as a 'model' for the same.

Judging by political chronicles and academic commentary, Northern Ireland has had more than its fair share of 'lessons' to share - ironic, for a country that makes use of every opportunity to stress its exceptionality and that has, as a consequence, been far too slow to listen to wisdom from elsewhere. Indeed, the Northern Ireland 'model' has already come full circle: from being trumpeted by New Labour apparatchiks in time for the 1998 Agreement's ten year anniversary (and, noncoincidentally for Tony Blair's move to become the Quartet's 'envoy to the Middle East') to being ridiculed by rhetoric-weary local activists (cf. Wilson, 2010). Professor Timothy White's collection thus draws interest because it does not fall obviously into the category of either legacy-creation or rhetoric-correction.

Edited by a US-based academic with an enduring interest in Ireland, the book draws together an interdisciplinary group of academics from across North America and the UK (though notably not Northern Ireland itself) to cover such topics as third party intervention, nationalism, grassroots change, and community development. Notably, the Foreword to the book is written by Martin Mansergh, a long-standing adviser to Fianna Fáil party leaders and Taoisigh [prime ministers] in the Republic of Ireland. He played his own part in the multiparty talks of the mid-1990s and it is impossible not to read his own 'legacy' motivations in in his comments in the Foreword. Mansergh's emphasis here on the need for 'a certain constructive ambiguity', plus the importance of basing peace on 'the reality of the community divide' is clearly directed at some of the critics of the Northern Ireland 'model' (this reviewer among them) who complain that it has tended to reify rather than transform the contested political identity binary. 
White's editorial role has been performed well; he draws strong conclusions from across the diversity of chapters and the chapters themselves are for the most part well-honed and to the point. He summarises the lessons raised by the contributing authors in the first chapter; some of these (such as 'minimal preconditions' and 'inclusivity') noticeably correspond with the features of the 'Northern Ireland model' frequently reiterated by Blairite supporters which (as O'Kane, 2010, has noted) sit better with the type of power-sharing arrangement that which had to be accepted after the St Andrews Agreement (i.e. between Sinn Féin and the DUP) than the one which the moderate SDLP and UUP had led in agreement on in 1998. In fact, White makes haste to move beyond the interminable debate about the most accurate term that may be used to describe the design of the power sharing arrangement in the 1998 Agreement; this helps to get to analysis of the lessons very quickly but in so doing perhaps does not reflect quite enough on why it is that this debate (about consociationalism) has drawn quite so much energy and attention from commentators. This debate is so heated because the architecture of the Agreement reflects a certain assumption about the nature of the conflict itself; if it is a misreading, or distortion, of the conflict, the risk is that it has given incredible power to parties and narratives that seem best-positioned to benefit from a binary divide - this is a point that the book as a whole struggles to avoid.

The chapters most likely to be of interest to the readership of this particular journal are the few that directly address the specific issue of identity change. Various contributing authors emphasise the need for the marginalisation of violence (and presumably violent actors) in order to create space to prioritise common short term needs and shared grounds for identity-creation; some examine this process in more detail. The chapter by Wendy Ann Wiedenhoft Murphy and Mindy Peden goes a step further in 'internationalising' the case of Northern Ireland by considering the effects of diasporic experience on Ulster Scots identification. They argue that influences back into Northern Ireland from the American expression of Ulster Scots identity (such as through the Ulster American Folk Park) helps to moves this identity away from 'intractable essentialisms' (p.95) towards a hybridity and diversity which the authors assume to be more conducive to peace.

Their case study chapter is complemented by the broader scope of Landon Hancock's, which analyses the 'widening' of identity in Northern Ireland and a subsequent shift in the salience of conflict-oriented identities. He claims that the peace process has allowed non-conflict related aspects of people's identities and roles to come to the fore ('work, home, family, local community') as their primary identification. Drawing on evidence from polls, interviews and newspaper editorials, Hancock argues that there has thus been a reordering of the 'hierarchies' of identity so that the newly dominant forms of identity may be mundane (e.g. there is little evidence for a common overarching European or Northern Irish identity) but are nonetheless conducive to peaceful relations. However, he concludes by emphasising that there is still a need to move away from an environment within which party leaders use the notion of 'identity threat' to stimulate political support and action - another reminder of the inescapable significance of the architecture of the political Agreement itself.

The second element of particular interest to readers of this journal is the discussion around truth as a means of reconciliation. A chapter by White, Andrew Owsiak and Meghan Clarke on 'Extending peace to the grassroots' contains an interesting comparison with experience in South Africa and its Truth and Reconciliation Commission. The authors conclude that Northern Ireland requires an 'improved associational life that successfully integrates Catholics and Protestants in social networks that create the interpersonal trust, social capital, and civil society necessary for a fully functioning democracy' (p256). They argue that, in order to do so, groups will need to 'address the past and construct a shared vision of the future'. This is all very well, but the question as to why it is that 
Northern Ireland does not yet have the conditions in which groups can do this - at any level - is one that suggests that it may yet be too soon for drawing many lessons from Northern Ireland.

There is a difference between learning lessons from a peace process and presenting outcomes as models for elsewhere - the lines are somewhat blurred throughout this book. For instance, the lesson White outlines (p.16) to 'support moderates and marginalize spoilers' is all well and good but it is worth remembering that the two largest parties now in the NI Executive would have been easily characterized by many as 'spoilers' in the early days of the Agreement; to emphasise the moderation of individual characters within these parties seems too particular to be of much use as a 'lesson' for other countries. Part of the problem here is the notion that the 'model' leads the way in showing others how to make the intractable negotiable, whereas in actual fact, for most peace processes, the outstanding lesson could be summed up in just a few words: "don't make the same mistakes we did". William Hazleton's chapter, subtitled 'Lessons best learned at home', is, therefore, an invaluable inclusion in this book. His comment in chapter two (p.38) is absolutely correct: Northern Ireland's lessons are retrospective - an effort to explain how and why certain events happened and particular decisions were made. In this sense, he argues that it would be premature to seek to find prescription or policy guidance from here to elsewhere; instead, he claims, at best, Northern Ireland's experience can offer insights into similar problems faced elsewhere and perhaps (he here concurs with President Clinton) inspiration to others.

In a section of his chapter in which he discusses the problem of contentious cultural events in Northern Ireland, Landon Hancock remarks: 'The moral valuation of talking has risen higher than the traditional value of rights' (p.76). He premises this claim on the assessment that the loyalist community has increasingly found it necessary to seek negotiation and accommodation around local issues of contention; grassroots leaders, Hancock implies, realise that blunt insistence on having their community's cultural 'rights' respected will no longer suffice as a strategy for maintaining their community's status and cohesion. The second text to be reviewed here, Jennifer Curtis' Human Rights as War by Other Means, may be seen as a thorough analysis of that particular point: what is the role played by human rights in Northern Ireland's peace process? However, her argument is rather different to the assumption made by Hancock; Curtis contends that the 'talking' being done by community leaders in situations such as contested cultural events does not represent a diminishing valuation of rights but actually reframes these rights in a different way. Thus, talks are the new battles and rights are the new ammunition, but the conflict remains essentially the same: "our interests and identities are irreconcilable with yours".

The premise of this book - that 'rights' have been invoked to perpetuate conflict and division in Northern Ireland - is not in itself original (for instance, I was publishing, with Claire Mitchell, on this topic over a decade ago), but the approach taken to elaborating and understanding it (i.e. through social anthropology) offers illuminating insights. This could have been a text that centred on abstract discussion of discourses and ideologies; instead, this is a weighty monograph that displays a great deal of careful, empirical research and intellectual consideration in its genesis. Quotations from interviews with individuals are sensitively interspersed with evidence from historical archives, Police Service of NI statistics, and key texts, and the analysis is informed by political theory and intellectual influences from far beyond Northern Ireland. In light of this, the book's title seems somewhat crude and not a fair representation of the nuanced arguments that the author attempts to make.

Curtis admits that it is unsurprising that the allocation of rights by the Agreement to conflicting political collectivities has served to reproduce difference. What she does emphasise, however, is 
that there is potential for transformation at the local level through the connection to broader terms of reference (which, as noted above, tend to be rarely used in the myopic political discourse of the six counties). Curtis traces the ways in which the movement from a discourse on civil rights to human rights in Northern Ireland reflects now an apparent ability to distinguish between political, legal, economic and social rights - a process that reflects developments in the sphere of international cooperation.

What Curtis has managed to do is demonstrate both the potential that this offers for progressing debates and ideas in Northern Ireland beyond the unionist/nationalist stand-off whilst at the same time showing why a rights based discourse is insufficient as the basis for conflict transformation per se. For example, she notes the difficulties that human rights talk has in addressing non-state violence. The central role of the state in relation to the recognition and protection of human rights means that claims regarding the failure or even abuses of the state in that regard benefit from an internationalist perspective. However, human rights abuses by non-state actors who deny the legitimacy of the state and who form alternative understandings of rights and duties of citizens (ones based on ideology rather than law) is a common problem in ethnic conflicts and one which makes their resolution quite so difficult.

One of the most welcome aspects of the book is Curtis' drawing in of a fresh perspective on the alltoo-familiar debate about cultural contestation in Northern Ireland, namely in relation to LGBT rights and the 'Pride parade'. Arguably the book does not give enough space to topics like these, which show the potential of rights discourse to move a conflict beyond a crass us/them framework into a more reasonable reflection of daily life. In this way, Curtis shows that Martin Mansergh's reference (noted above) to the 'reality of the community divide' is only one interpretation; there are many other realities in NI that are competing to be heard. In this changing context, the trope of protests at a cultural celebratory parade in Belfast takes an unusual form - this time not of nationalist residents opposing Orange parades but fundamentalist Christians protesting at Belfast Pride. In her analysis of the challenges faced by the LGBT movement in Northern Ireland, Curtis claims that this changing context and the use of rights language to push for progression in law and society is an example here of 'intimations of peace'.

At the time of writing this review, the proposed inclusion of a 'Conscience clause' in equality legislation in Northern Ireland (supported by an unusual alliance between unionist parties and the Catholic Church), to allow businesses to refuse to offer services to some people if it clashes with their religious convictions, demonstrates Curtis' warning that the quest for agency by any group particularly when it centres on a discourse of rights - is a political quest and will therefore struggle to avoid the mire of local political contestation. We saw this, too, in the recent debate about welfare reform, which could have focused much more on economic rights rather than becoming another unionist/nationalist standoff. Ironically, it appears that the attempts to internationalise the peace process, through a focus on lessons to export from the NI model, or even on human rights, can actually serve to reinforce the impression of a singular, dominant reality: that of a two-sided conflict. For true progress to be made, the voices that lead the way in 'internationalising' the Northern Ireland peace process should not be those of established political leaders claiming their legacy but need to come from a new generation of citizens who are ready to claim their future.

\section{References}

Hayward, K. and Mitchell, C. (2003) 'Discourses of equality in post-Agreement Northern Ireland', Contemporary Politics Vol. 9 (3), 293-312. 
O'Kane, Eamonn (2010) 'Learning from Northern Ireland? The uses and abuses of the Irish model', British Journal of Politics and International Relations, Vol.12, No.2, pp.239-256.

Wilson, Robin (2010) The Northern Ireland Experience of Conflict and Agreement. A model for export? Manchester: Manchester University Press.

Katy Hayward is a Senior Lecturer in Sociology in Queen's University Belfast. Her teaching, research and publications use political sociology to explore key issues of conflict and change on the island of Ireland. Her recent publications include the co-edited works Nationalism, Territory, and Organized Violence (with Niall Ó Dochartaigh, 2013), Political Discourse and Conflict Resolution: Debating Peace in Northern Ireland (with Catherine O'Donnell, 2011), and The Europeanization of Party Politics in Ireland - North and South (with Mary C. Murphy, 2010). 